\title{
OPTIMIZATION OF CUTTING PROCESS OF AISI 316 L CORROSION RESISTANT STEEL WITH HYDRO ABRASIVE JET
}

\author{
Miroslav Duspara, Valnea Starčević, Antun Stoić
}

Original scientific paper

Modern technological development is characterized by discovering a large number of new and advanced materials for which the standard machining processing that currently prevails in industry from technical and economic point of view is often difficult to achieve. Due to the inability of fulfilling all the requirements of modern technology, application of non-conventional machining processes such as hydro abrasive cutting is more significant. The paper focuses on the verification of the thesis whether the standard operations such as milling could be replaced by non-conventional machining process of hydro abrasive cutting while maintaining the required quality of the processed surface. If the thesis is accepted, it is necessary to specify the maximum cutting depth to which to achieve the required quality of surface material machining is possible with minimal consumption of resources.

Keywords: analysis of variance; hydroabrasive waterjet cutting; process optimization; surface quality

Optimizacija procesa rezanja korozijski postojanog čelika AISI 316 L hidro abrazivnim mlazom

Izvorni znanstveni članak Suvremeni tehnološki razvoj karakterizira pronalazak velikog broja novih i naprednih materijala za koje je obrada standardnim postupcima koji trenutno prevladavaju u industriji s tehničkog i ekonomskog stajališta često teško izvodiva. Zbog nemogućnosti ispunjavanja svih zahtjeva suvremene tehnologije sve je značajnija primjena nekonvencionalnih postupaka obrade poput hidro abrazivnog rezanja. Članak se fokusira na provjeru teze mogu li se standardni postupci poput glodanja zamijeniti nekonvencionalnim postupkom hidro abrazivnog rezanja uz zadržavanje zahtijevane kvalitete obrađivane površine. Ukoliko se teza prihvaća, potrebno je odrediti maksimalnu dubinu rezanja do koje je moguće ostvariti traženu kvalitetu površine uz minimalni utrošak resursa.

Ključne riječi: analiza varijance; kvaliteta površine; optimizacija; rezanje hidro abrazivnim mlazom

\section{Introduction}

With more applications of hydro abrasive jet cutting technology there is a need to qualitatively and quantitatively describe cutting process in order to select and optimize the process parameters and predict the cutting performance. The mathematical models for the major cutting performance measures are therefore required [1]. Over the last decades, a great deal of research effort has been directed to develop such models. While most of the developed models are focused to estimate the depth of cut for different materials, some other models are also developed to express other cutting characteristics like material removal rate, the shape of kerf profile, kerf surface roughness and kerf width under certain cutting conditions. Chen et al. also [1, 2] investigated the influence of main variables on the depth of cut with an objective to find the optimum traverse speed. However, the optimum traverse speed may deteriorate other cutting performance measures such as machined surface quality. With an application of numerical analysis it is possible to determine the optimal cutting parameters where the traverse speed may produce maximum depth of cut and at the same time does not sacrifice surface quality.

\section{Numerical optimization}

Optimization in engineering terms represents a procedure of maximization or minimization of goal or goals within available resources, with the satisfaction of limitations that objectively exist [3]. It is assumed that the problem has a "surplus" of internal degrees of freedom, which are becoming variables of the optimization process. Unlike classical application of numerical methods in analysis, in the optimization each iteration involves analysis performing (system response simulation). Synthesis is not conducted by testing all potential solutions and then generating new solutions. Processes and procedures of optimization have an increasing importance and ever growing area of application.Today's logic in the development of products, services and process does not mean finding a solution that satisfies all the conditions, but finding a solution that satisfies all the conditions while minimizing the costs of all resources, or maximizing the objectives (so called solution excellence criteria). With enforcement of optimization, sequence of generated solutions leads to a way of better fulfilling of conditions, while at the same time fulfilling the limitations.

In that order, optimization is an iterative process regardless of the fact whether it is conducted in a classical way or supported by numerical methods $[4,5]$.

\section{Definition of problem and setting the experimental conditions}

In the experimental part of the work it was investigated whether in some conditions the technology of hydro abrasive jet cutting can replace conventional technology (in this case face milling and circumferential milling) and achieve the required quality of machined surface during the austenitic corrosion resistant steel X2CrNiMo $17-12$ - 2 (AISI 316 L) cutting. Corrosion resistant steel belongs to the group of materials difficult to cut and process with conventional methods that are currently dominant in industry. During the processing of AISI $316 \mathrm{~L}$ steel on classical milling machine it is possible to achieve required quality of machined surface in the range of $3,2 \div 6,3 \mu \mathrm{m}$ (Fig. 1). That value of surface 
roughness fulfils most of the exploitation requirements. Besides cutting parameters, economic feasibility of the cutting process is taken into account, i.e. maximum cutting speed is required with minimal consumption of abrasive particles [6].

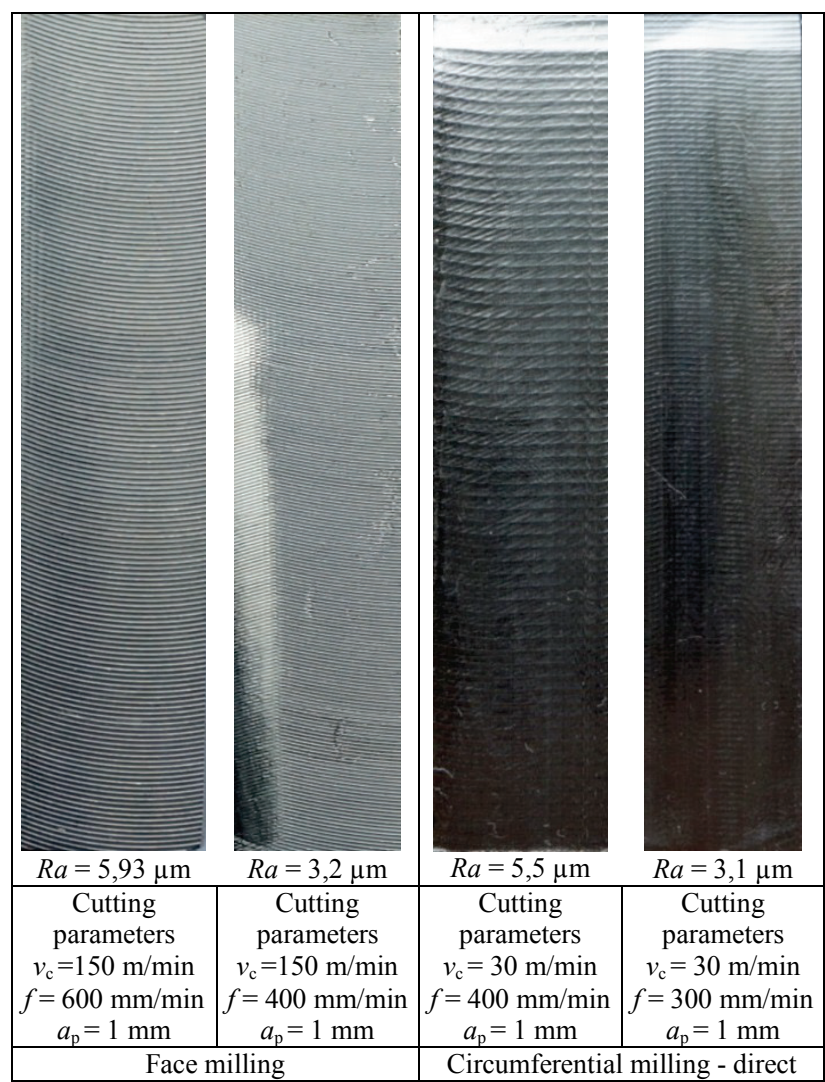

Figure 1 Review of milled surface roughness results of AISI $316 \mathrm{~L}$ corrosion resistant steel [6]

Table 1 Process factors and their values by levels

\begin{tabular}{|c|c|c|c|c|c|c|c|}
\hline \multirow[b]{2}{*}{ Factors } & \multirow[b]{2}{*}{.5 } & \multirow[b]{2}{*}{ 志 } & \multicolumn{5}{|c|}{ CODED VALUES OF PARAMETERS } \\
\hline & & & $\frac{\bar{d}}{0} \underset{0}{0}$ & 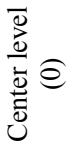 & 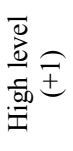 & i & 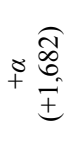 \\
\hline $\begin{array}{c}\text { Traverse } \\
\text { speed }\end{array}$ & $V_{\mathrm{f}}$ & $\mathrm{mm} / \mathrm{min}$ & 25 & 30 & 35 & 21,8 & 38,4 \\
\hline $\begin{array}{l}\text { Cutting } \\
\text { pressure }\end{array}$ & $p$ & $\mathrm{MPa}$ & 310 & 325 & 340 & 299 & 350 \\
\hline $\begin{array}{l}\text { Abrasive } \\
\text { mass flow }\end{array}$ & $m_{\mathrm{a}}$ & $\mathrm{kg} / \mathrm{min}$ & 0,35 & 0,4 & 0,45 & 0,32 & 0,49 \\
\hline
\end{tabular}

In the experiment, specimens were cut with a Teen King 23020 hydro abrasive jet cutter of company Sigmat from Gromačnik, Slavonski Brod. For increasing the cutting parameters and higher productivity, particles of abrasive material Barton garnet $M E S H$ granulation 80 were added in water jet. Three main parameters of cutting were selected with the greatest influence on quality of the machined surface (traverse speed, pressure and mass flow rate) and they varied on 2 levels $(+1,682$ and $-1,682)$. The range of process factors and their levels are shown in Tab. 1. Cutting parameters were chosen based on own practical experience and on cutting parameters calculator from waterjet machine for the chosen group material AISI and thickness of the material.

\section{Design of experiment (DOE)}

After the cutting operation, control and surface roughness measurements were carried out on the observed surface of specimen. Surface roughness was measured by portable surface roughness test Mitutoyo SJ 301 SurfTest on cutting depth of $25 \mathrm{~mm}$ according to the standard ISO 4287:1997 (Fig. 2). In the mentioned cutting zone striations forming on the surface of material is pronounced, and the attention of many researchers is focused on the research of striation formation mechanism and improving the quality in observed zone.

From all types of available parameters for describing the surface quality, $R a$ parameter was chosen, which defines the arithmetic mean deviation of the surface profile, measurement is simple, standardized and generally applied [7].

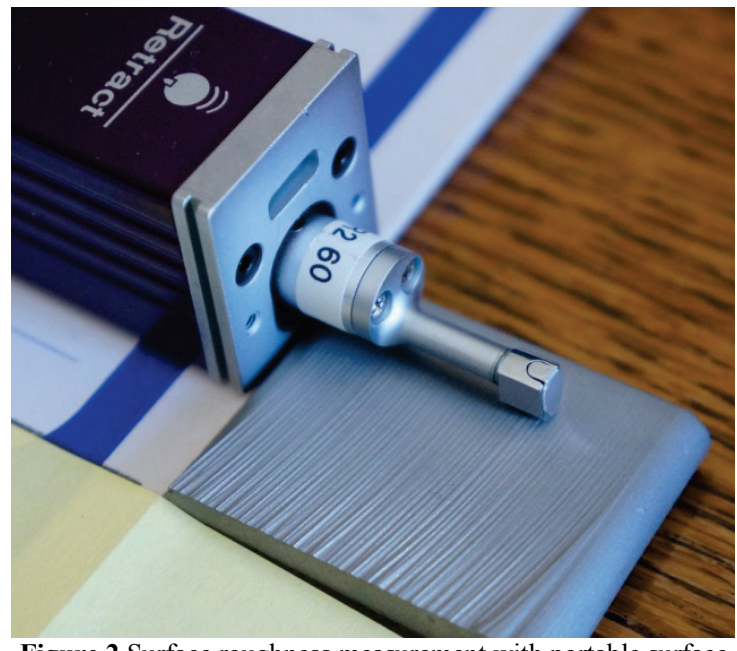

Figure 2 Surface roughness measurement with portable surface roughness test Mitutoyo SJ 301 SurfTest

Table 2 Values of surface roughness on the cutting depth of $25 \mathrm{~mm}$

\begin{tabular}{|c|c|c|c|c|c|c|}
\hline \multirow[b]{2}{*}{ 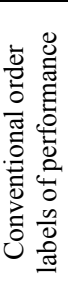 } & \multirow[b]{2}{*}{ 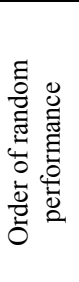 } & \multirow[b]{2}{*}{ 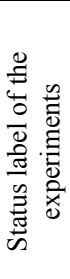 } & \multicolumn{3}{|c|}{ PROCESS FACTORS } & \multirow[b]{2}{*}{ 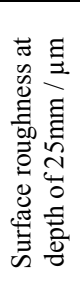 } \\
\hline & & & $\begin{array}{l}\sum_{0}^{\infty} \\
0 \\
\vdots \\
0 \\
0 \\
0 \\
0\end{array}$ & 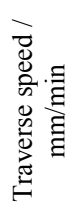 & 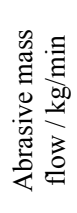 & \\
\hline 1 & 5 & 5 & 310 & 25,00 & 0,35 & 7,92 \\
\hline 2 & 11 & 11 & 340 & 25,00 & 0,35 & 7,02 \\
\hline 3 & 10 & 10 & 310 & 35,00 & 0,35 & 13,87 \\
\hline 4 & 14 & 14 & 340 & 35,00 & 0,35 & 12,97 \\
\hline 5 & 2 & 2 & 310 & 25,00 & 0,45 & 6,44 \\
\hline 6 & 3 & 3 & 340 & 25,00 & 0,45 & 6,34 \\
\hline 7 & 16 & 16 & 310 & 35,00 & 0,45 & 13,46 \\
\hline 8 & 1 & 1 & 340 & 35,00 & 0,45 & 9,19 \\
\hline 9 & 12 & 12 & 300 & 30,00 & 0,40 & 10,75 \\
\hline 10 & 15 & 15 & 350 & 30,00 & 0,40 & 7,6 \\
\hline 11 & 17 & 17 & 325 & 21,60 & 0,40 & 4,93 \\
\hline 12 & 13 & 13 & 325 & 38,40 & 0,40 & 14,77 \\
\hline 13 & 7 & 7 & 325 & 30,00 & 0,32 & 12,57 \\
\hline 14 & 9 & 9 & 325 & 30,00 & 0,48 & 6,78 \\
\hline 15 & 18 & 18 & 325 & 30,00 & 0,40 & 7,89 \\
\hline 16 & 6 & 6 & 325 & 30,00 & 0,40 & 7,40 \\
\hline 17 & 4 & 4 & 325 & 30,00 & 0,40 & 7,80 \\
\hline 18 & 8 & 8 & 325 & 30,00 & 0,40 & 7,00 \\
\hline
\end{tabular}

According to the characteristics and physical limitations of the experiment, there are several designs of 
experiment. Central - composite design provides a description of process while avoiding a large number of runs. In order to verify suitability of the chosen model, curvature of response surface and determine "pure" errors in experimental area, 3 more conditions were added to the central point, so the total number of runs needed for this experiment will be 18 (Tab. 2).

\section{Statistical evaluation of model and regression diagnostic}

The results of surface roughness measurement are generated with available software package for statistical analysis Design Expert 9. The suitability of the model is determined with $F$-test, and significance of model is determined with analysis of variance (ANOVA). With analysis of variance, besides creating a regression model, analysis of errors in experimental area will be conducted and potential non-linearity within the specified relations detected $[8,9]$.

First step in statistical analysis is to determine the type of transformation of the response surface. Based on obtained results, transformation is not required for this case. In the next step, based on the minimum sum of squared deviations program suggests the optimal model for analysed case. Analysis of variance showed that obtained cutting zone can be optimally described with the reduced quadratic model.

In order to eliminate the members of the model with negligible influence, reduction of the members is conducted with value Prob $>F$ less than 0,05 (5\%). Analysis of variance (Tab. 3) shows that dominant cutting parameter with the greatest influence on quality of machined surface is traverse speed.

Table 3 Analysis of variance for regression model $R a_{25}$

\begin{tabular}{|c|c|c|c|c|c|}
\hline $\begin{array}{c}\text { Source of } \\
\text { variation }\end{array}$ & $\begin{array}{c}\text { Sum of } \\
\text { square }\end{array}$ & $\begin{array}{c}\text { Degree of } \\
\text { freedom } \\
\text { (dof })\end{array}$ & $\begin{array}{c}\text { Mean } \\
\text { square }\end{array}$ & $F$ - value & $\begin{array}{c}P \text { - value } \\
\text { Prob }>F\end{array}$ \\
\hline Model & 150,23 & 6 & 25,04 & 29,70 & $<0,0001$ \\
\hline $\begin{array}{c}\mathrm{A}- \\
\text { Pressure }\end{array}$ & 9,63 & 1 & 9,63 & 11,42 & 0,0061 \\
\hline $\begin{array}{c}\mathrm{B}- \\
\text { Traverse } \\
\text { speed }\end{array}$ & 107,52 & 1 & 107,52 & 127,54 & $<0,0001$ \\
\hline $\begin{array}{c}\mathrm{C}- \\
\text { Abrasive } \\
\text { mass flow }\end{array}$ & 18,95 & 1 & 18,95 & 22,48 & 0,0006 \\
\hline $\mathrm{A}^{2}$ & 4,19 & 1 & 4,19 & 4,97 & 0,0475 \\
\hline $\mathrm{B}^{2}$ & 8,39 & 1 & 8,39 & 9,95 & 0,0092 \\
\hline $\mathrm{C}^{2}$ & 7,16 & 1 & 7,16 & 8,50 & 0,0141 \\
\hline Residuals & 9,27 & 11 & 0,84 & - & - \\
\hline Lack of fit & 8,77 & 8 & 1,10 & 6,58 & 0,0745 \\
\hline Pure error & 0,50 & 3 & 0,17 & - & - \\
\hline Total & 159,50 & 17 & & - & - \\
\hline
\end{tabular}

\section{Obtained results during the experiment}

After simplification of the process, final form of surface roughness prediction for regression model $R a_{25}$ is given with expression (1)

$$
\begin{aligned}
& R a_{25}=366,04817-1,7191 \cdot p-1,39330 \cdot v_{\mathrm{f}}- \\
& -264,35629 \cdot m_{\mathrm{a}}+2,55872 \cdot E-0,05 \cdot p^{2}+ \\
& +0,032574 \cdot v_{f}^{2}+0,032574 \cdot v_{\mathrm{f}}+300,99572 \cdot m_{a}^{2}
\end{aligned}
$$

"Rough" deviation of certain points of real measured values of the observed property is determined with a diagnostic tool. Based on this display, it is possible to determine the optimum function.

In Fig. 3 plots of estimated variance for regression model $R a_{25}$ are shown three - dimensional with constant mass flow rate $m_{\mathrm{a}}=0,4 \mathrm{~kg} / \mathrm{min}$. [8, 9]

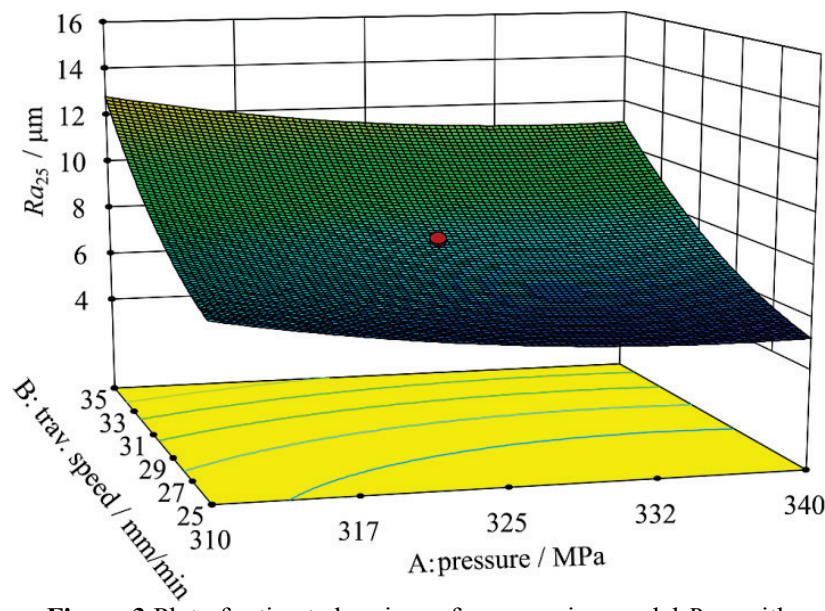

Figure 3 Plot of estimated variance for regression model $R a_{25}$ with constant mass flow rate $m_{\mathrm{a}}=0,4 \mathrm{~kg} / \mathrm{min}$

From obtained plot it can be seen that traverse speed has a higher slope, ie. change of traverse speed will have greater impact on the quality of the machined surface in relation to the cutting pressure, and the higher the cutting depth the impact of cutting speed on the quality of the treated surface will be stronger. Mass flow, as a parameter of cutting has no significant impact on the quality of the machined surface.

In order to check the assumption that errors are approximately normally distributed with expectation 0 and constant variance, and determine additional conditions that will contribute to the quality of regression model, analysis of remains [1] is often applied in statistical analysis.

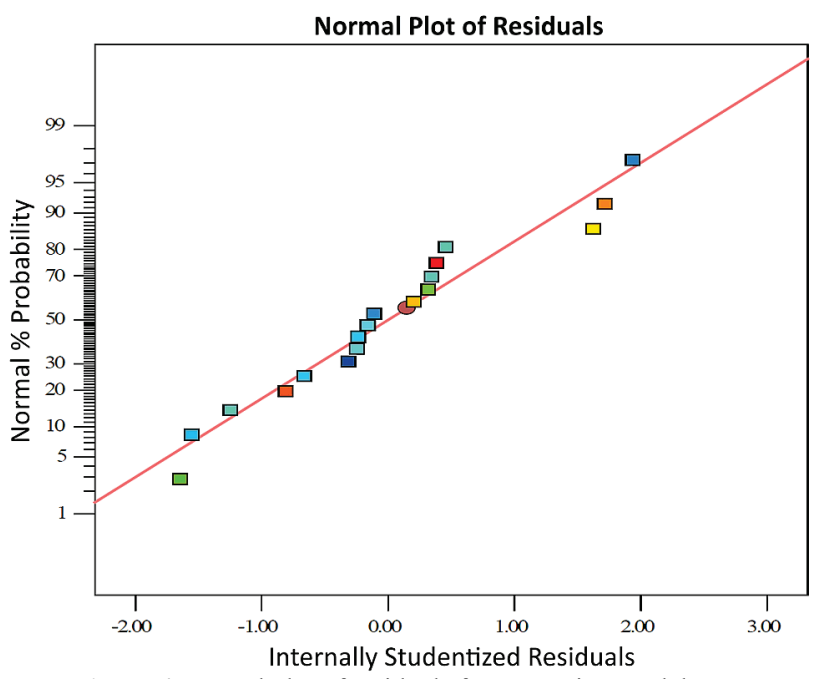

Figure 4 Normal plot of residuals for regression model $R a_{25}$

For testing this assumption normal plot of residuals is used because it is one of the most effective and efficient ways to test the normality of remains (Fig. 4). 
The remains are divided by the estimated standard deviation (which is calculated according to Student's $t$ distribution) along the line called Henry's line, sign of normal distribution. Fig. 4 shows that there is no major scattering of data in the experimental area, what is a sign that the selected model is described well, and it validates that transformation is not required.

By applying the statistical tool Influence it is necessary to check whether there is any data within the model that deviates significantly from the average and that value is called Outlier. Outliers are defined as extreme values of variable which have a disproportional influence on model (they control it), compared to the other states of experiment, which do not deviate from the average. The influence of each state of experiment on regression model is shown in Fig. 5.

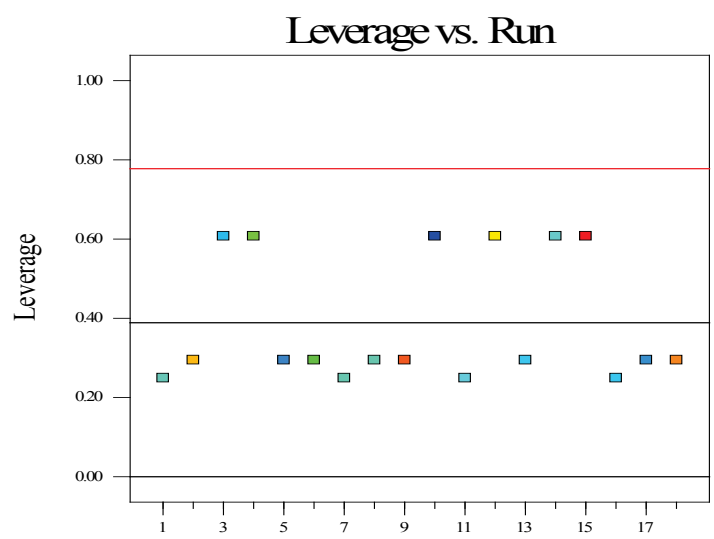

Run Nunber

Figure 5 Influence of state of experiment on model

From Fig. 5 can be concluded that all states of experiment are moving within the range $0,00 \div 1,00$, and that there are no outliers.

\section{Optimization of model}

Optimization of model is applied in searching for optimal solution from a set of available solutions. Software tools that have a statistical support, such as the Design Expert, allow optimization of model by defining the value of the parameters for achieving the desired results. The program finds optimal combination of 2 or more responses of observed variables in a way that first limits are chosen within the value of observed variables, and then algorithm for optimization runs. The success of the numerical optimization is evaluated through desirability. For the needs of the study, numerical optimization will be conducted in the cutting zone at the depth of $25 \mathrm{~mm}$.

According to the classification proposed by Hashish [1], this zone is defined as a deformation wear zone because of pronounced striations on the surface of material produced after hydro abrasive jet cutting. Surface roughness in observed zone moves within the range 4,93 $\div 14,77 \mu \mathrm{m}$, thus there is a need for additional treatment due to weak surface quality which causes the increase of machining costs. Statistical analysis has shown that traverse speed has a greater influence on the quality of cutting compared to pressure and mass flow rate, and it is necessary to find the maximum possible traverse speed with a minimal mass flow rate of abrasive particles.

The range of values within which the optimization will be conducted is $4,93 \mu \mathrm{m}$ (as a lower boundary) and 6,32 (as upper boundary and also target point) (Fig. 6).

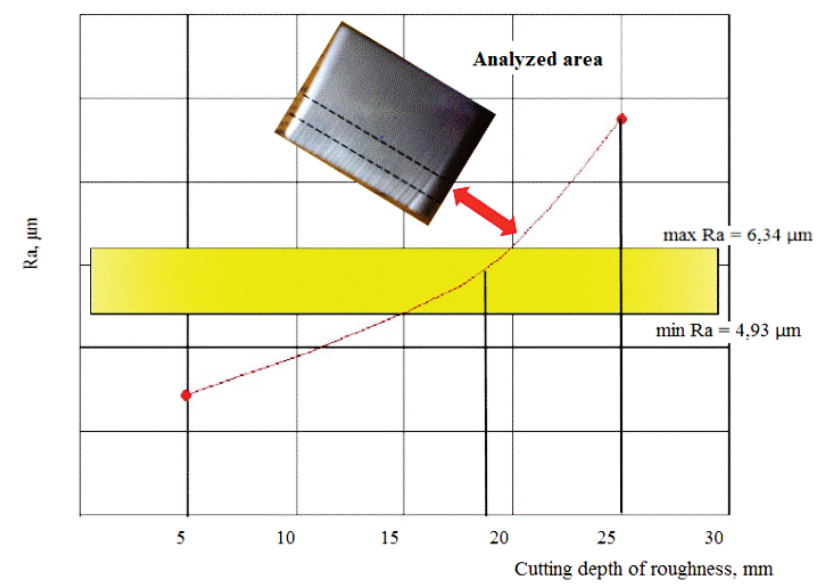

Figure 6 Area of optimization for regression model $R a_{25}$ [6]

Table 4 Potential solutions of numerical analysis for regression model $R a_{25}$

\begin{tabular}{|c|c|c|c|c|c|}
\hline \multirow{2}{*}{ 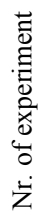 } & \multicolumn{3}{|c|}{ PROCESS FACTORS } & \multirow{2}{*}{ 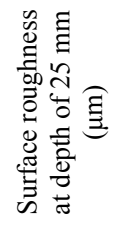 } & \multirow{2}{*}{ 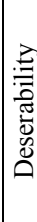 } \\
\hline & $\begin{array}{c}\text { Pressure } \\
\text { (Mpa) }\end{array}$ & $\begin{array}{c}\text { Traverse } \\
\text { speed } \\
(\mathrm{mm} / \mathrm{min})\end{array}$ & $\begin{array}{l}\text { Abrasive } \\
\text { mass flow } \\
\text { (kg/min) }\end{array}$ & & \\
\hline 1 & 325,2 & 28,29 & 0,416 & 6,34 & 1 \\
\hline 2 & 311,3 & 25,06 & 0,445 & 6,34 & 1 \\
\hline 3 & 323,9 & 27,83 & 0,400 & 6,34 & 1 \\
\hline 4 & 3393 & 29,11 & 0,448 & 6,34 & 1 \\
\hline 5 & 321,8 & 28,00 & 0,424 & 6,34 & 1 \\
\hline 6 & 321,0 & 25,41 & 0,384 & 6,34 & 1 \\
\hline 7 & 3385 & 25,09 & 0,368 & 6,34 & 1 \\
\hline 8 & 337,7 & 29,01 & 0,421 & 6,34 & 1 \\
\hline 9 & 315,7 & 26,21 & 0,414 & 6,34 & 1 \\
\hline 10 & 337,8 & 27,30 & 0,386 & 6,34 & 1 \\
\hline 11 & 323,2 & 26,16 & 0,386 & 6,34 & 1 \\
\hline 12 & 332,8 & 26,20 & 0,376 & 6,34 & 1 \\
\hline 13 & 3213 & 27,50 & 0,411 & 6,34 & 1 \\
\hline 14 & 325,9 & 28,65 & 0,431 & 6,34 & 1 \\
\hline 15 & 327,5 & 26,89 & 0,387 & 6,34 & 1 \\
\hline 16 & 316,2 & 26,94 & 0,439 & 6,34 & 1 \\
\hline 17 & 318,9 & 25,57 & 0,446 & 6,34 & 1 \\
\hline 18 & 339,0 & 28,47 & 0,405 & 6,34 & 1 \\
\hline 19 & 331,1 & 26,34 & 0,378 & 6,34 & 1 \\
\hline 20 & 337,0 & 27,27 & 0,385 & 6,34 & 1 \\
\hline 21 & 321,1 & 28,03 & 0,441 & 6,34 & 1 \\
\hline 22 & 325,6 & 27,88 & 0,405 & 6,34 & 1 \\
\hline 23 & 338,1 & 27,06 & 0,383 & 6,34 & 1 \\
\hline 24 & 314,8 & 26,48 & 0,432 & 6,34 & 1 \\
\hline 25 & 337,4 & 29,15 & 0,449 & 6,34 & 1 \\
\hline 26 & 322,1 & 28,18 & 0,433 & 6,34 & 1 \\
\hline 27 & 336,4 & 28,90 & 0,416 & 6,34 & 1 \\
\hline 28 & 322,1 & 26,88 & 0,397 & 6,34 & 1 \\
\hline 29 & 321,8 & 27,61 & 0,412 & 6,34 & 1 \\
\hline
\end{tabular}

During the optimization process, it is necessary to take account of costs that arise during the cutting process. Considering that the abrasive has a relatively great share in total costs (approximately $60 \%$ ), it is necessary to find a combination of cutting parameters which will ensure minimal consumption of abrasive while maintaining the quality of surface in default value of $R a$ [6]. 


\section{Results and discussion}

Based on parameters, algorithm in the program suggests 29 potential solutions considered to have maximal desirability (or 1). That means it is possible to get optimal regression model with the required conditions in 29 possible combinations according to the limits of optimization (Tab. 4).

As the optimal solution, first choice recommended by the program is $\left(v_{\mathrm{f}}=28,291 \mathrm{~mm} / \mathrm{min}, p=325,4 \mathrm{MPa}\right.$ and $\left.m_{\mathrm{a}}=0,416 \mathrm{~kg} / \mathrm{min}\right)$.

Results of optimization also can be displayed graphically using the countor plot and 3D surface. Graphical optimization is a fast and simple method of optimization suitable for problems that involve up to 3 variables, based on principle of overlapping twodimensional responses of observed variables within the boundaries.

The part of area within the boundaries that is common for all areas of response is considered to be optimal. Fig. 7 shows graphical optimization of problem with: a) contour and b) 3D surface.

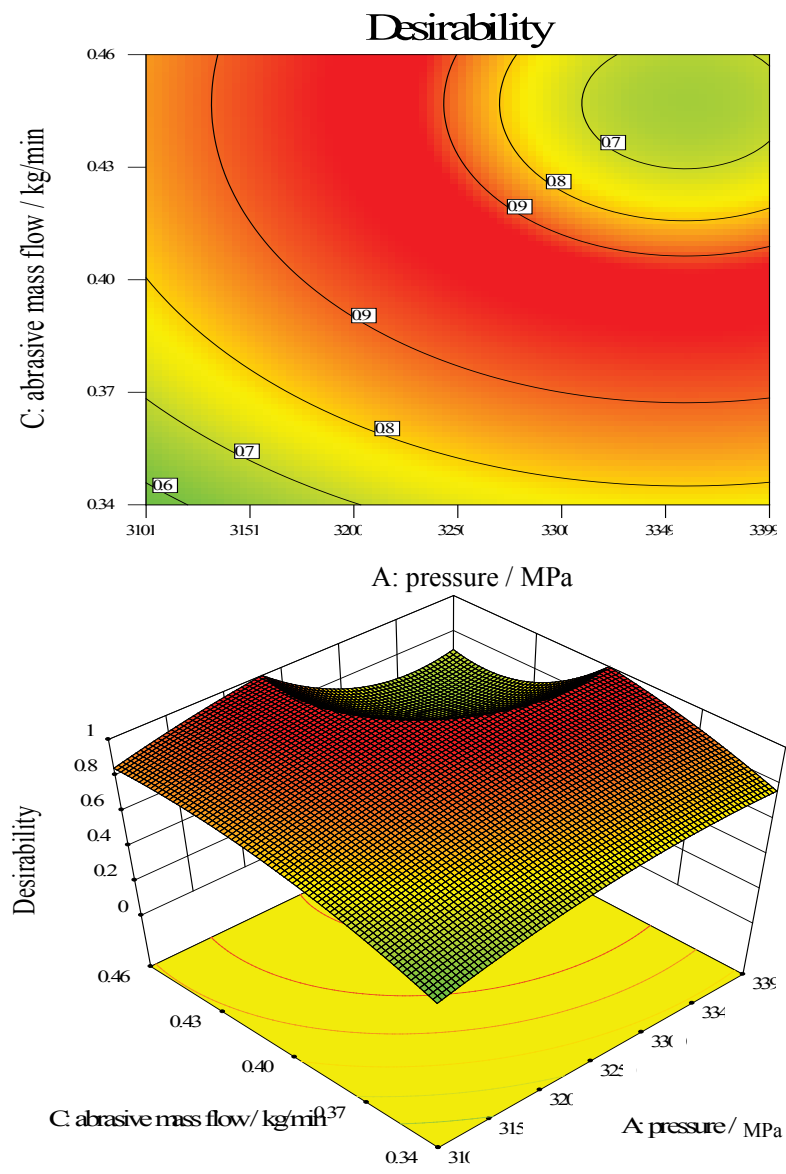

Figure 7 Graphical display of optimization: a) contour and b) 3D surface

With application of software LabVIEW calculation of cutting expenses was made to determine how much the change of individual cutting parameter will influence overall costs (Tab. 5). The largest items in the share of costs will be abrasive material (approximately $60 \%$ ) and electric energy $(30,53 \%)$, while the costs of water and consumable parts of the machine (orifice and focusing tube) are relatively low.
Table 5 Calculation of machining costs for achieving the required surface quality

\begin{tabular}{|l|c|c|c|}
\hline \multicolumn{1}{|c|}{ Resources } & $\begin{array}{c}\text { Consuption of } \\
\text { resources }\end{array}$ & Unit price, Kn & $\begin{array}{c}\text { Share of } \\
\text { costs, \% }\end{array}$ \\
\hline Abrasive & $14,29 \mathrm{~kg}$ & 30 & 59,18 \\
\hline Water & 62,851 & 0,751 & 1,48 \\
\hline Electrical energy & $11,904 \mathrm{~kW} \cdot \mathrm{h}$ & 15,47 & 30,53 \\
\hline Focusing tube & $0,007 \mathrm{pc}$ & 3,72 & 7,33 \\
\hline Orifice & $0,00744 \mathrm{pc}$ & 0,744 & 1,46 \\
\hline
\end{tabular}

Comparing the results obtained by the analysis of variance (with probability of $95 \%$ ) and optimization it can be concluded that the quality of machined surface with hydro abrasive jet and with conventional technology (milling) can be compared.

\section{Conclusion}

In this work the thesis about comparability of machined surface quality with hydro abrasive jet and milling was tested. Examining was conducted on specimens of austenitic corrosion resistant steel AISI 316 L with variation of 3 technological parameters of cutting (traverse speed, pressure and mass flow rate) on 2 levels.

Based on data obtained with measuring at the depth of $25 \mathrm{~mm}$, statistical analysis was performed with software Design Expert 9. After analysis of variance, the following conclusions were drawn:

- Traverse speed has a greater influence on quality of machined surface compared to the other cutting parameters (pressure and mass flow rate) and their combination $\left(\mathrm{A}^{2}, \mathrm{~B}^{2}\right.$ and $\left.\mathrm{C}^{2}\right)$, in the pressure range $310 \div 340 \mathrm{MPa}$

- Further analysis revealed that residuals are normally distributed along Henry's line and the data from regression model are within the boundaries.

In order to examine the hypothesis about comparability of surface quality machined by hydro abrasive jet and milling, optimization was conducted. Results of optimization showed that the technology of hydro abrasive jet cutting can be compared with milling up to the cutting depth of $19,8 \mathrm{~mm}$, because up to that depth the required surface roughness is achieved.

Decision support software such as LabVIEW allows finding the optimal solution that will satisfy the required criteria of quality while reducing machining costs.

\section{Acknowledgement}

The authors would like to express their thanks to the company Sigmat from Gromačnik, Slavonski Brod and CEO Mato Sigurnjak, B.Sc. for expert guidance and counseling in experimental part of work.

The authors are also thankful to Jeroen Keswiel, Area Export manager from company Eurogrit, Netherlands for supplying less common abrasive materials.

\section{References}

[1] Abdel-Rahman, A. A.; El Domiaty, A. A. Maximum depth of cut for ceramics using abrasive watejet tehnique. // Wear. 218 , 2(1998), pp. 216-222. DOI: 10.1016/S0043$1648(98) 00204-X$ 
[2] $\mathrm{Xu}, \mathrm{S}$. Modeling in Cutting Process and Cutting Performanse in Abrasive Waterjet Machining with Controled Nozzle Oscilation. // PhD theesis, Scool of Engeneering Systems, Queensland University of Technology, Queensland, 16 237, 2005, 238 pp.

[3] Singaravel, B.; Selvaraj, T. Optimization of machining parameters in turning operation using combined TOPSIS and AHP method. // Tehnicki Vjesnik-Technical Gazette. 22, 6(2015), pp. 1475-1480, DOI: 10.17559/TV20140530140610

[4] Drmač, Z.; Marušić, M.; Singer, S.; Hari, V.; Singer, S.; Rogina, M.; Numerička analiza, Zagreb; Sveučilište u Zagrebu; Prirodoslovno - matematički fakultet; matematički odjel. http://web.math.pmf.unizg.hr/ rogina/ 2001096/num anal.pdf (09.02.2015)

[5] Kinik, D.; Gánovská, B.; Hloch, S.; Monka, P.; Monková, K.; Hutyrová, Z.; On-line monitoring of technological process of material abrasive water jet cutting. // Tehnički vjesnik. 22, 2(2015), pp. 351-357. DOl: 10.17559/TV20130904111939

[6] Duspara, M. Istraživanje rezljivosti korozijski postojanog čelika AISI $316 \mathrm{~L}$ mlazom vode. // PhD thesis, Slavonski Brod, Strojarski fakultet u Slavonskom Brodu, 2014, 135 pp.

[7] Hloch, S.; Stoić, A.; Kozak, D.; Samardžić, I.; Novak Marcinčin; J.; Modrak, V; Rezanje mlazom vode, 1. izdanje, Slavonski Brod, Strojarski fakultet u Slavonskom Brodu, 2011, 122 pp.

[8] Glogović, Z. Utjecaj parametara plinskog naštrcavanja na svojstva nanešenog sloja. // PhD thesis, Zagreb, Fakultet strojarstva i brodogradnje u Zagrebu, 2010, 213 pp.

[9] Cajner, H. Višekriterijsko adaptivno oblikovanje planova pokusa. // $\mathrm{PhD}$ thesis, Zagreb, Fakultet strojarstva i brodogradnje u Zagrebu, 2011, 164 pp.

\section{Author's addresses}

dr. sc. Miroslav Duspara

Mechanical Engineering Faculty in Slavonski Brod,

J. J. Strossmayer University of Osijek,

Trg Ivane Brlić Mažuranić 2, 35000 Slavonski Brod, Croatia

E-mail: Miroslav.Duspara@sfsb.hr

Valnea Starčević, mag. ing. mech.

Mechanical Engineering Faculty in Slavonski Brod,

J. J. Strossmayer University of Osijek,

Trg Ivane Brlić Mažuranić 2, 35000 Slavonski Brod, Croatia

E-mail: vstarcevic@sfsb.hr

prof. dr. sc. Antun Stoić

Mechanical Engineering Faculty in Slavonski Brod,

J. J. Strossmayer University of Osijek,

Trg Ivane Brlić Mažuranić 2, 35000 Slavonski Brod, Croatia

E-mail: Antun.Stoic@sfsb.hr 